\title{
Hydrocortisone Increases the Vinblastine-Induced Chromosomal Damages in L929 Cells Investigated by the Micronucleus Assay on Cytokinesis- Blocked Binucleated Cells
}

\author{
Tahere Ebrahimipour ${ }^{1}$, Farhang Haddad ${ }^{1}$, Maryam Moghaddam Matin ${ }^{2}$, Ali Moghimi ${ }^{1}$
}

Received: 31.12 .2016

Accepted: 25.01.2017

\section{ABSTRACT}

Background: Stress may cause damages to DNA or/and change the ability of the cells to overcome these damages. It may also cause irregularities in the cell cycle and induce abnormal cell divisions through glucocorticoid-dependent functions. The abnormal cell divisions, in turn, lead to chromosomal mal-segregation and aneuploidy. In this study, the effects of the stress hormone, hydrocortisone (HYD), were investigated on the induced chromosomal abnormalities by vinblastine (VIN) during cell cycle in L929 cells.

Methods: This work was performed in winter 2013 at Department of Biology, University of Ferdowsi, Mashhad, Iran. Cultured cells were divided into different groups including control, VINtreated, HYD treated and VIN+HYD co-treated cells. The induced chromosomal damages were investigated by micronucleus assay in cytokinesis-blocked binucleated cells.

Results: Although HYD by itself did not increase the micronuclei $(\mathrm{Mn})$ frequency, co-treatment of cells with VIN and HYD led to significant increase $(P<0.05)$ in the frequency of $\mathrm{Mn}$ in comparison to control and VIN treated groups.

Conclusion: Cells treated with stress hormone are more sensitive to damages induced by VIN. Therefore, stress may not directly result in genetic instability, it can increase the harmful effects associated with other genotoxic agents.

Keywords: Binucleated Cells, Hydrocortisone, L929 Cell, Micronucleus Assay, Vinblastine.

\section{IJT 2017 (3): 1-6}

\section{INTRODUCTION}

Living organisms are trying to maintain a complex equilibrium called homeostasis. Stress is one of the most important stimuli; threaten the homeostasis of the cells and organisms. When the homeostasis is being threatened, numerous biological systems are activated including neuroendocrine axis. Atressed animals react by the mobilization of the energy from stored nutrients and prevent further energy storage. An increase in cardiovascular rate will be followed to facilitate the delivery of oxygen and glucose to tissues. During the stress response, a slow-down of anabolic processes and the suppression of cell division and growth, reproduction, and inflammatory and immune responses occur [1]. Environmental stress leads to increase in the level of glucocorticoids steroid hormones with 21carbons produced by adrenal cortex. They physiologically modulate body homeostasis and coordinate adaptive responses to stress. Their activity affects the vast majority of organs and tissues [2].

There are reports on the capability of stress in inducing cellular changes. Environmental stress could shorten the telomeres of the chromosomes in affected individuals [3]. Any change in cell homeostasis could also lead to changes in the cell cycle rhythm and division [4]. External stressors could clearly change the expression profile of the genes involved in cell cycle, cell signaling, adhesion and immune response [5]. Moreover, hydrocortisone, up-regulated during stress situation, could induce changes in genes involved in metabolism, cell cycle regulation and cell-cell or cell-extracellular matrix communications [6]. Hydrocortisone is also able to produce clastogenic effects and cause structural chromosomal damages [7].

1. Department of Biology, Ferdowsi University of Mashhad, Mashhad, Iran.

2. Department of Biology and Institute of Biotechnology, Cell and Molecular Biotechnology Research Group, Ferdowsi University of Mashhad, Mashhad, Iran.

*Corresponding Author: E-mail: haddad@um.ac.ir 
Chromosomal abnormalities are responsible for a wide range of malfunctions in human. One of our main concerns regarding the chromosomal abnormalities is their role in inducing cancer [8, 9]. There are several studies suggesting this role and the list is growing. From all kinds of chromosomal abnormalities, aneuploidy is the most important factor involved in cancer formation [10-15].

Chromosome mal-segregation is the mechanism leading to aneuploidy. In a normal cell division, the chromatids of a duplicated chromosome will detach and migrate to opposite poles. However, in some cases, chromosomes will not migrate equally either spontaneously or because of external stimuli. The unequal migration of chromosomes to opposite division poles results in aneuploidy. The aneuploidy could occur because of both chromosome loss and/or chromosome nondisjunction.

Vinblastine (VIN) is a member of Vinica alkaloids. It is a strong aneugen, which exerts its effects by preventing microtubule polymerization and spindle formation [16]. VIN-treated cells show a high frequency of aneuploidy. The VINinduced frequency of chromosome loss is detectable by micronucleus assay. In this assay, the small nucleus in cytoplasm, called micronucleus, represents the chromosome lagged behind during anaphase of cell division [17-19].

A synergistic effect of acute restraint stress was reported on VIN-induced Mn frequency in an in vivo study [20]. However, we could not conclude if the increase in the Mn frequency was because of stress-induced malfunctioning of the cellular mechanisms monitoring the genetic integrity or perhaps by increased blood pressure causing more VIN to enter the bone marrow.

In the present study, the effects of hydrocortisone, one of the stress hormones, on VIN-induced instability was investigated on L929 cell lines. With the results of this in vitro study, it would be possible to explain the direct or indirect effects of stress on chromosome mal-segregation.

\section{MATERIALS AND METHODS}

This work was performed in winter 2013 at Department of Biology, University of Ferdowsi, Mashhad, Iran.

\section{Culture of L929 Cells}

The L929 cells (Pasteur Institute, Iran), were grown in DMEM (Dulbecco's Modified
Eagle's Medium) (Gibco) supplemented with 10\% FBS(Fetal Bovine Serum) (Biosera), in a humidified atmosphere with $5 \% \mathrm{CO}_{2}$ (Figure1). The sub-culturing was performed using $0.25 \%$ trypsin/EDTA when the cells reached $80 \%$ confluences.

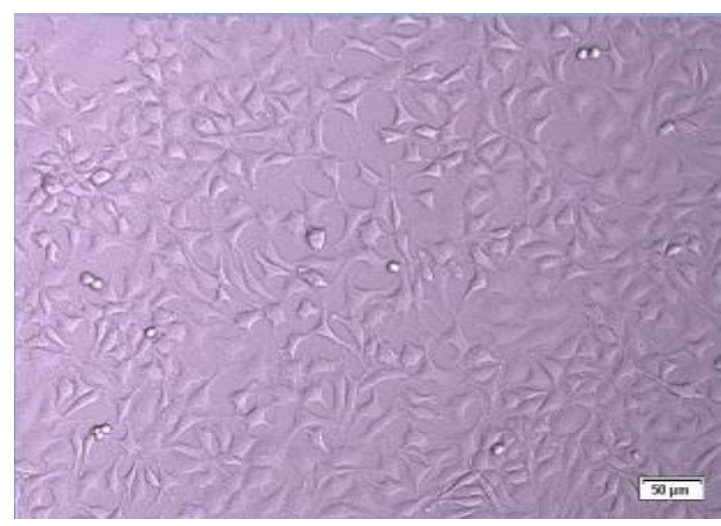

Figure 1. Cultured L929 cells.

\section{Test Materials}

\section{Hydrocortisone (HYD)}

One mg of hydrocortisone sodium succinate powder (Rotexmedica) was dissolved in $1 \mathrm{ml}$ sterile distilled water. The HYD was added to L929 cell cultures at final concentrations of 50, 100 and $500 \mu \mathrm{g} \cdot \mathrm{ml}^{-1}$.

\section{Vinblastine (VIN)}

To be able to choose the optimal dose for VIN treatment, two different concentrations of 3 and $5 \mathrm{ng} \cdot \mathrm{ml}^{-1}$ of VIN (Gedeon Richter LTD, Budapest, Hungary) were prepared from a stock

${ }^{-1}$ and administered in each T25 flask with $5 \mathrm{ml}$ medium. When required, HYD treated cells were co-treated with $3 \mathrm{ng} \cdot \mathrm{ml}^{-1}$ of VIN.

\section{Cytochalasin B}

One mg of cytochalasin B (Sigma-Aldrich) was dissolved in $1 \mathrm{ml}$ DMSO (dimethylsulfoxide). L929 cells were exposed to $4 \mathrm{ng} \cdot \mathrm{ml}^{-1}$ cytochalasin $\mathrm{B}, 24 \mathrm{~h}$ before harvesting.

\section{Treatment Groups}

Cells were divided into 4 experimental groups including control, VIN-treated cells, HYDtreated cells and a combination of HYD and VIN (HYD+VIN co-treated) treated cells. Each treatment was performed in three separate cultures. 


\section{Experimental Procedure}

Cells were treated with different doses of HYD when they reached $80 \%$ confluency (usually $48 \mathrm{~h}$ post culture initiation). VIN was added $2 \mathrm{~h}$ post HYD treatment when required. Cytochalasin $\mathrm{B}$ was added $3 \mathrm{~h}$ after VIN treatment and cells were harvested $24 \mathrm{~h}$ later.

\section{Cell Harvest}

Cells were trypsinized and centrifuged for $10 \mathrm{~min}$ at $100 \mathrm{gr}$. The supernatants were removed and the pellets were re-suspended in a fixator, acetic acid: methanol (1:3). After re-centrifugation for $10 \mathrm{~min}$ at $100 \mathrm{gr}$, the cell pellets were smeared on clean slides. The smears were stained with $10 \%$ Giemsa solution. Six slides per treatment were scored ( 2 slides for each flask).

\section{Micronucleus Assay and Binary Index}

Almost 1200 binucleated cells (Bi) were scored blindly from each slide (Figure 2A). The ratio of micronucleated binucleates $(\mathrm{MnBi})$ (Figure 2B, C) was calculated in each slide. Binary index (BI) was calculated as the proportion of $\mathrm{Bi}$ in total of mono- and Bi cells scored.

$\mathrm{BI}=($ Binucleated cells/Total of Mono- and Binucleated cells) x 100 .

\section{Statistical Analysis}

The statistical analysis was performed using SPSS software 18 (Chicago, IL, USA). The differences between control and treated cells as well as between treated groups were analyzed by one-way analysis of variance (ANOVA).

\section{RESULTS}

\section{Selection of Optimal Dose of Vinblastine}

There was a significant difference in the frequency of $\mathrm{MnBi}$ (Figure 2) between cells treated with two different concentrations of VIN and the control group $(\mathrm{F}(2,21)=5.57, P<0.05)$ (Table 1). However, the frequencies of $\mathrm{MnBi}$ between the cells treated with two concentrations of 3 and 5 ng. $\mathrm{ml}^{-1}$ of VIN did not show any statistically significant difference. L929 cells treated with both doses of VIN showed a lower binary index compared to control $(\mathrm{F}(2,20)=$ 6.37, $P<0.05$ and $P<0.01$ for 3 and $5 \mathrm{ng} \cdot \mathrm{ml}^{-1}$ of VIN, respectively). Comparison of binary index in different groups revealed a lower division activity

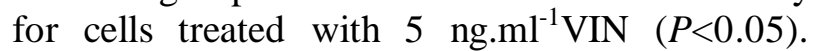
Since numerical and/or structural chromosomal aberrations that lead to $\mathrm{Mn}$ are because of cell division, the dose of $3 \mathrm{ng} \cdot \mathrm{ml}^{-1}$ of VIN, which had the lower negative effect on cell division was applied to the cells in culture for the rest of experiments.

\section{MN Induction in Hydrocortisone Treated Group}

The HYD treatment alone did not increase the frequency of $\mathrm{MnBi}$ (Table 2). Moreover, no significant difference was observed between cells treated with three different doses of HYD. However, binary index decreased significantly in these cells in comparison to the control $(\mathrm{F}(3,21)$ $=7.54, P<0.01$ ).
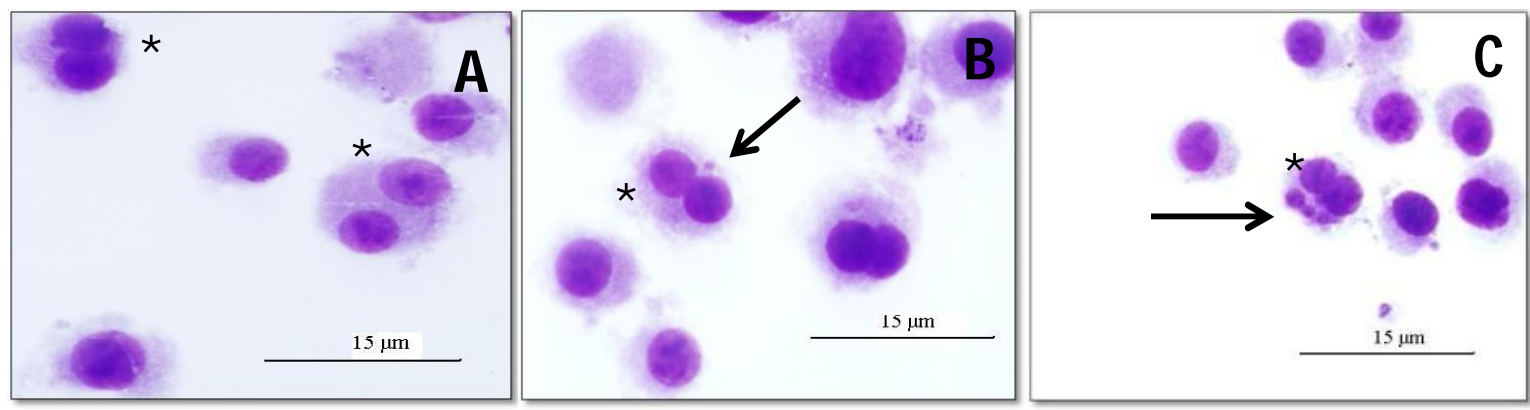

Figure 2. The binucleated cells (A). Binucleated cell with one and three micronuclei (MnBi) (B, C). Strikes represent binucleated cells and arrows are pointing to the micronuclei.

Table 1. MnBi and Binary index in control, Vinblastine and hydrocortisone treated cells.

\begin{tabular}{cccc}
\hline & Dose & MnBi\% $($ mean \pm SD) & Binary Index (mean \pm SD) \\
\hline Control & $0.0 \mathrm{ng}^{-m^{-1}}$ & $1.43 \pm 0.54$ & $46 \pm 9.87$ \\
Vinblastine & $3{\mathrm{ng} \cdot \mathrm{ml}^{-1}}^{-1}$ & $11.38 \pm 8.54^{\mathrm{a}}$ & $33.63 \pm 11.89^{\mathrm{a}}$ \\
& $5 \mathrm{ng} \cdot \mathrm{ml}^{-1}$ & $8.16 \pm 6.23^{\mathrm{a}}$ & $29.69 \pm 3.88^{\mathrm{b}, \mathrm{c}}$ \\
\hline
\end{tabular}

Statistical differences with control are represented as ${ }^{\mathrm{a}}(P<0.05)$ and ${ }^{\mathrm{b}}(P<0.01)$, c: statistical difference between two treatment groups $(P<0.05)$ 
Table 2. The frequency of micronucleus and binary index between hydrocortisone and hydrocortisone + vinblastine treated groups. Results are expressed as mean $\pm \mathrm{SD}$.

\begin{tabular}{cllcc}
\hline & & $\begin{array}{c}\text { MnBi\% } \\
(\text { mean } \pm \text { SD })\end{array}$ & $\begin{array}{c}\text { Binary Index } \\
(\text { mean } \pm \text { SD })\end{array}$ \\
\hline $\begin{array}{c}\text { Control } \\
\text { Treatment }\end{array}$ & & \multicolumn{1}{c}{ Dose } & $1.43 \pm 0.54$ & $46 \pm 9.87$ \\
& Vinblastine & $3 \mathrm{ng} \cdot \mathrm{ml}^{-1}$ & $11.38 \pm 8.54^{\mathrm{a}}$ & $33.63 \pm 11.89^{\mathrm{a}}$ \\
& Hydrocortisone & $50 \mu \mathrm{g} \cdot \mathrm{ml}^{-1}$ & $3.10 \pm 1.65$ & $33.00 \pm 3.24^{\mathrm{a}}$ \\
& & $100 \mu \mathrm{g} \cdot \mathrm{ml}^{-1}$ & $2.80 \pm 1.09$ & $33.20 \pm 6.61^{\mathrm{a}}$ \\
& & $500 \mu \mathrm{g} \cdot \mathrm{ml}^{-1}$ & $3.43 \pm 1.72$ & $29.53 \pm 4.16^{\mathrm{a}}$ \\
& Hydrocortisone+ & $50 \mu \mathrm{g} \cdot \mathrm{ml}^{-1}$ & $6.52 \pm 1.79^{\mathrm{a}}$ & $30.57 \pm 1.86^{\mathrm{a}}$ \\
& 3 ng.ml ${ }^{-1}$ of Vinblastine & & & \\
& & $100 \mu \mathrm{g} \cdot \mathrm{ml}^{-1}$ & $9.75 \pm 3.49^{\mathrm{a}}$ & $29.97 \pm 5.46^{\mathrm{a}}$ \\
& & $500 \mu \mathrm{g} \cdot \mathrm{ml}^{-1}$ & $79.22 \pm 7.44^{\mathrm{b}, \mathrm{c}, \mathrm{d}}$ & $28.55 \pm 5.58^{\mathrm{a}}$ \\
\hline
\end{tabular}

Statistical differences with control are represented as ${ }^{a}(P<0.05)$ and ${ }^{\mathrm{b}}(P<0.01)$, c: Statistical difference with other treatment groups $(P<0.01)$; d: Statistical difference with vinblastine treated cells $(P<0.05)$

\section{Comparison of Micronuclei Frequencies between Cells Treated with Combination of Hydrocortisone + Vinblastine and Hydrocortisone}

Table 2 represents the frequency of $\mathrm{MnBi}$ in cells co-treated with different doses of HYD+VIN. The frequency of $\mathrm{MnBi}$ was significantly higher in co-treated cells compared to cells treated with $\operatorname{HYD}(\mathrm{F}(5,33)=465.34$, $P<0.01)$. All VIN-treated cells, either alone or with HYD, showed significantly higher frequency of $\mathrm{MnBi}$ compared to the control group. Interestingly, this increase in the highest dose was 39 folds in comparison to the control.

The HYD+VIN co-treated cells showed a significant increase in $\mathrm{MnBi}$ frequency at 500

${ }^{-1}$ of hormone compared to VIN-treated cells $(P<0.01)$. However, for the two other doses, there were no significant differences with the VINtreated cells.

Decrease in binary index suggested that the HYD + VIN co-treated cells had a lower division activity compared to control $(\mathrm{F}(3,21)=20.07$, $P<0.01)$. The cells co-treated with highest dose of HYD and vinblastine represented the lowest binary index, although it was not statistically different from other treated groups.

\section{DISCUSSION}

Genotoxic effects of stress have already been suggested in an in vivo study [20]. Prolonged stressed mice, treated with doses of vinblastine exhibited a higher frequency of $\mathrm{Mn}$ in their polychromatic erythrocytes compared to nonstressed ones. However, it was not clear if this effect was because of the synergistic ability of stress in vinblastine-induced chromosomal aberrations or simply because of increase in blood pressure and entry of more vinblastine to the bone marrow. To clarify this problem, the effects of stress hormone, hydrocortisone, was investigated in L929 cells in vitro in the presence of vinblastine.

Vinblastine is a potent aneugen, which is able to induce chromosome mal-segregation including chromosome loss and/or nondisjunction [21]. Cells treated with vinblastine showed an increase in the frequency of $\mathrm{Mn}$ in micronucleus assay, which was the result of chromosome loss [22]. Similarly, in the present study vinblastinetreated cells represented a significantly higher frequency of Mn compared to control. Increase in the frequency of Mn could be the result of either chromosome breaks or chromosome loss during cell division. The only possible way to differ these two is to perform centromere labelling of the chromosomes. In this way, the Mn produced by chromosome break will show no labeling however, the Mn produced by whole chromosome lost during cell cycle will be labeled. In many studies, treating the cells with different doses of vinblastine has been led to significant increase in centromere positive Mn [19, 23, 24]. Due to the strong aneugenic capability of VIN, the increase in the frequency of $\mathrm{Mn}$ in this study was also the result of increase in chromosome loss.

In this study, hydrocortisone did not have any effect on micronucleus formation, representing no harmful effect on structure and/or segregation of chromosomes. However, the ability of hydrocortisone in inducing chromosomal 
abnormalities in human lymphocytes and Crepis capillaries test system has been suggested [7, 25]. The difference might be associated with different cell lines used and/or higher doses of hormone and longer treatment time. Increase in the time interval between hydrocortisone treatment and the cell harvest time might lead to increase in the frequency of micronuclei in $\mathrm{Bi}$.

Treatment of L929 cells with doses of hydrocortisone reduced the binary index, which is the result of the lower cell division activity. The anti-mitotic effect of hydrocortisone has been suggested. From all steroid hormones, the hydrocortisone was the most effective in inhibiting proliferation of cultured cells [26].

Hydrocortisone could provide the sensitivity in the treated cells for vinblastine-induced chromosome loss. The hydrocortisone-treated cells represented a higher frequency of Mn when treated with vinblastine. Enhanced sensitivity of stressed cells to external stimuli such as oxidative stressors has been confirmed. Although stressed cells did not show any DNA damages compared to control, oxidative treatment revealed higher than normal damages to DNA [27]. The harmful effect of stress hormones was suggested on genome integrity of the cell and its division fidelity [28, 29]. Increase in the sensitivity of cells after chronic psychogenic stress to environmental mutagenic elements was also suggested [27]. Cells under treatment of the hydrocortisone were unable to overcome the aneugenic damages caused by VIN due to the perturbed genetic situation.

\section{CONCLUSION}

Environmental stress could disturb the crucial monitoring mechanisms of genetic stability of the cells, which might not necessarily lead to genomic abnormality itself but could increase the susceptibility of the cells to aneugen and/or clastogen agents. Stress hormone treatment does not increase genomic instability but co-treatment with other genotoxic stimuli could synergistically increase their harmful effects on the genome.

\section{ACKNOWLEDGEMENTS}

The Grant from Ferdowsi University of Mashhad, Iran, supported this research (project no. 3/14862). The authors declare that there is no conflict of interest.

\section{REFERENCES}

1. Darnaudery M, Maccari S. Epigenetic programming of the stress response in male and female rats by prenatal restraint stress. Brain Res Rev 2008; 57(2): 571-85.

2. Fietta P, Fietta P, Delsante G. Central nervous system effects of natural and synthetic glucocorticoids. Psychiatry Clin Neurosci 2008; 63(5): 613-22.

3. Zahran S, Snodgrass JG, Maranon DG, Upadhyay C, Granger DA, Bailey SM. Stress and telomere shortening among central Indian conservation refugees. Proc Natl Acad Sci USA 2015; 112(9): E928-E936.

4. Dickmeis $\mathrm{T}$, Lahiri $\mathrm{K}$, Nica G, Vallone $\mathrm{D}$, Santoriello C, Neumann, et al. Glucocorticoids Play a Key Role in Circadian Cell Cycle Rhythms. PLoS Biol 2007; 5(4): e78-9.

5. Nater UM, Whistler T, Lonergan W, Mletzko T, Vernon SD, Heim C. Impact of acute psychosocial stress on peripheral blood gene expression pathways in healthy men. Biol Psychol 2009; 82(2): 125-32.

6. Lu L, Li T, Williams G, Petit E, Borowsky M, Walker WA. Hydrocortisone induces changes in gene expression and differentiation in immature human enterocytes. Am J Physiol Gastrointest Liver Physiol 2011; 300(3): 425-32.

7. Koshpaeva ES, Semenov VV. Clastogenic and Anticlastogenic Activity of Glucocorticoid Hormones Hydrocortisone and Its Synthetic Analogs Prednisolone and Dexamethasone. Bull Exp Biol Med 2013; 155(1): 78-80.

8. Mitelman F. Recurrent chromosome aberrations in cancer. Mutat Res 2000; 462(2-3): 247-53.

9. Duesberg P, Li R, Fabarius A, Hehlmann R. The chromosomal basis of cancer. Cell Oncol 2005; 27(5-6): 293-318.

10. Li R, Sonik A, Stindl R, Rasnick D, Duesberg P. Aneuploidy vs. gene mutation hypothesis of cancer: Recent study claims mutation but is found to support aneuploidy. Proc Natl Acad Sci USA 2000; 97(7): 3236-41.

11. Duesberg P, Li R, Rasnick D, Rausch C, Willer A, Kraemer A, et al. Aneuploidy Precedes and Segregates with Chemical Carcinogenesis. Cancer Genet Cytogenet 2000; 119(2): 83-93.

12. Duesberg P, Li R, Fabarius A, Hehlmann R. Aneuplodiy and cancer: from correlation to causation. Contrib Microbiol 2006; 13: 16-44.

13. Tanaka K, Hirota T. Chromosome segregation machinery and cancer. Canser Sci 2009; 100(7): 1158-65.

14. Hu Y, Ru N, Xiao H, Chaturbedi A, Hoa NT, Tian $\mathrm{XJ}$, et al. Tumor-Specific Chromosome MisSegregation Controls Cancer Plasticity by 
Maintaining Tumor Heterogeneity. PLoS One 2013; 8(11): 1-16.

15. Pihan GA. Centrosome dysfunction contributes to chromosome instability, chromoanagenesis, and genome reprograming incancer. Front Oncol 2014; 227: 1-26.

16. Okouneva T, Hill BT, Wilson L, Jordan MA. The effects of vinflunine, vinorelbine, and vinblastine on centromere dynamics. Mol Cancer Ther 2003; 2(5): 427-36.

17. Brunner M, Albertini S, Wurgler FE. Effects of 10 known or suspected spindle poisons in the in vitro porcine brain tubulin assembly assay. Mutagenesis 1991; 6(1): 65-70.

18. Wendell KL, Wilson L, Jordan MA. Mitotic block in Hella cells by vinblastine: Ultrastructural changes in kinetochore microtubule attachment and in centrosomes. J Cell Sci 1993; 104: 261-74.

19. Huber R, Salassidis K, Kulka U, Braselmann H, Bauchinger M. Detection of centromeres in vinblastine- and radiation induced micronuclei of human lymphocytes using FISH with an alpha satellite pancentromeric DNA probe. Environ Mol Mutagen 1996; 27(2): 105-9.

20. Malvandi MA, Haddad F, Moghimi A. Acute restraint stress increases the frequency of vinblastine-induced micronuclei in mouse bone marrow cells. Stress 2010; 13(3): 276-80.

21. Leopardi P, Marcon F, Dobrowolny G, Zijno A, Crebelli R. Influence of donor age on vinblastineinduced chromosome malsegregation in cultured peripheral lymphocytes. Mutagenesis 2002; 17(1): 83-8.

22. Lynch AM, Parry JM. The cytochalasin-B micronucleus/kinetochore assay in vitro: studies with 10 suspected aneugens. Mutat Res 1993; 287(1): 71-86.

23. Marshall RR, Murphy M, Kirkland DJ, Bentley KS. Fluorescence in situ hybridisation with chromosome-specific centromeric probes: a sensitive method to detect aneuploidy. Mutat Res 1996; 2(2): 233-45.

24. Zijno A, Marcon F, Leopardi P, Crebelli R. Analysis of chromosome segregation in cytokinesis-blocked human lymphocytes: nondisjunction is the prevalent damage resulting from low dose exposure to spindle poisons. Mutagenesis 1996; 11(4): 335-40.

25. Bali D, Singh JR, Singh H, Sandhu D. In vitro and in vivo genotoxicity evaluation of hormonal drugs. I. Hydrocortisone. Environ Mol Mutagen 1990; 16(4): 250-4.

26. Ponec M, de Hass C, Bachra BN, Polano MK. Effect of Glucocorticosteroids on primary human skin fibroblasts. I. Inhibition of the proliferation of cultured primary human skin and mouse L929 fibroblasts. Arch Derm Res 1977; 259: 177-23.

27. Dimitroglou E, Zafiropoulou M, Messini-Nikolaki N, Doudounakis S, Tsilimigaki S, Piperakis SM. DNA damage in a human population affected by chronic psychogenic stress. Int $\mathbf{J}$ Hyg Environ Health 2003; 206: 39-44.

28. Fischman HK, Pero RW, Kelly DD. Psychogenic stress induces chromosomal and DNA damage. Int J Neurosci 1996; 84(1-4): 19-221.

29. Ingel F, Platonova V, Katosova L. Human emotional stress, dioxin blood content and genetic damage in Chapaevsk town. Chemosphere 2001; 43(4-7): 989-98. 